\title{
Pituitary apoplexy presenting with bilateral oculomotor nerve palsy
}

\author{
Bik Ling Man, ${ }^{1}$ Yat Pang Fu ${ }^{2}$
}

${ }^{1}$ Department of Medicine and Geriatrics, Tuen Mun Hospital, Hong Kong, Hong Kong ${ }^{2}$ Department of Medicine, Tuen Mun Hospital, Hong Kong, Hong Kong

\section{Correspondence to} Dr Bik Ling Man, beli_man@yahoo.com

Accepted 2 October 2015

\section{DESCRIPTION}

An 82-year-old man with a history of pituitary macroadenoma, was admitted for sudden onset binocular diplopia and headache. Physical examination showed complete ptosis of both eyes (video 1). He had bilateral oculomotor nerve palsy and right abducens nerve palsy (videos 2 and 3). The horizontal vestibulo-ocular reflex was impaired. The pupillary reflex was also impaired (video 4). Visual field was normal and limb power was full. Serum sodium level was $112 \mathrm{mmol} / \mathrm{L}$ (N 136-145) and 9:00 cortisol

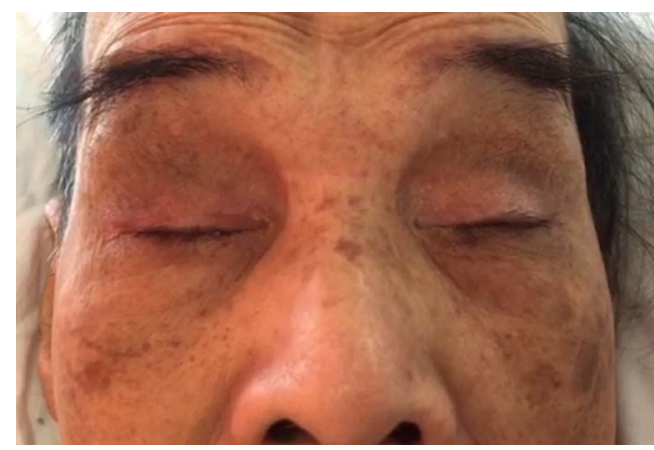

Video 1 Complete ptosis of both eyes.



Video 2 Bilateral oculomotor nerve palsy and right abducens nerve palsy.

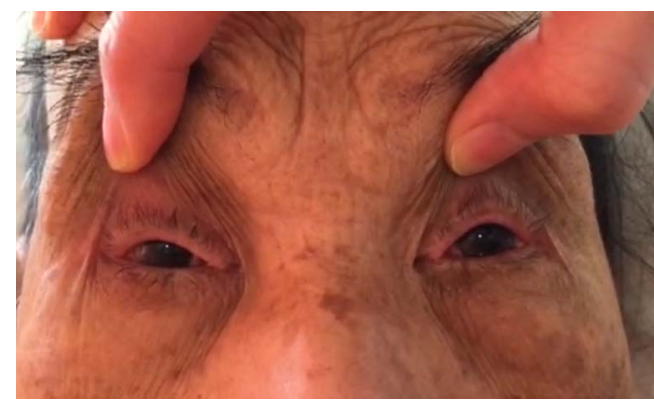

Video 3 Bilateral oculomotor nerve palsy and right abducens nerve palsy.

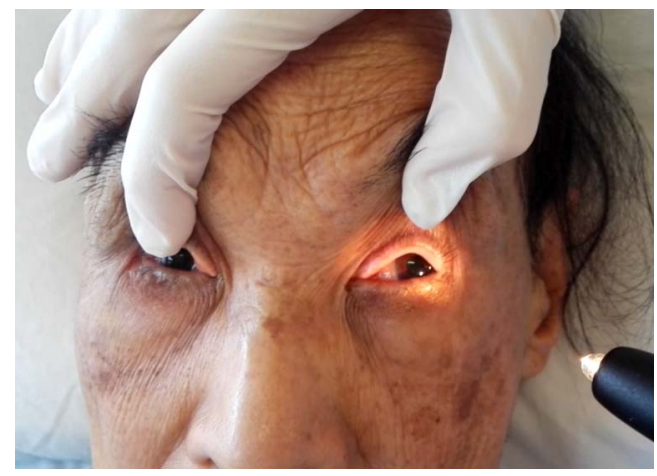

Video 4 Pupillary reflex was impaired.

level was $57 \mathrm{nmol} / \mathrm{L}$ (N 171-536). Thyroid function test was normal. MRI of the brain revealed a pituitary macroadenoma with haemorrhage abutting bilateral cavernous sinuses and optic chiasm (figures 1 and 2). Trans-sphenoidal total excision of pituitary tumour was urgently performed; the oculomotor nerve palsy improved partially after the operation.

Pituitary apoplexy presenting with bilateral oculomotor nerve palsy is rare. ${ }^{1} 2$ Pituitary apoplexy is a potentially life-threatening disorder characterised by sudden onset of headache, visual disturbances, ophthalmoplaegia and impairment of consciousness. It is caused by an infarct or haemorrhage of the pituitary gland. ${ }^{3}$ Acute secondary adrenal insufficiency, which is the major cause of mortality, is seen in about two-thirds of patients with pituitary apoplexy. Hypocortisolaemia increases vasopressin release from the posterior

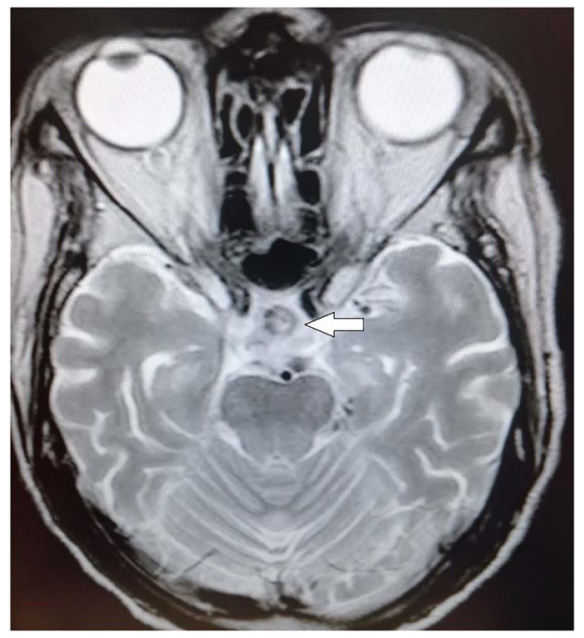

Figure 1 MRI T2W axial image shows heterogeneously hyperintense pituitary mass expanding the sella turcica, which is suggestive of subacute haemorrhage (arrow). T2W, T2-weighted. 


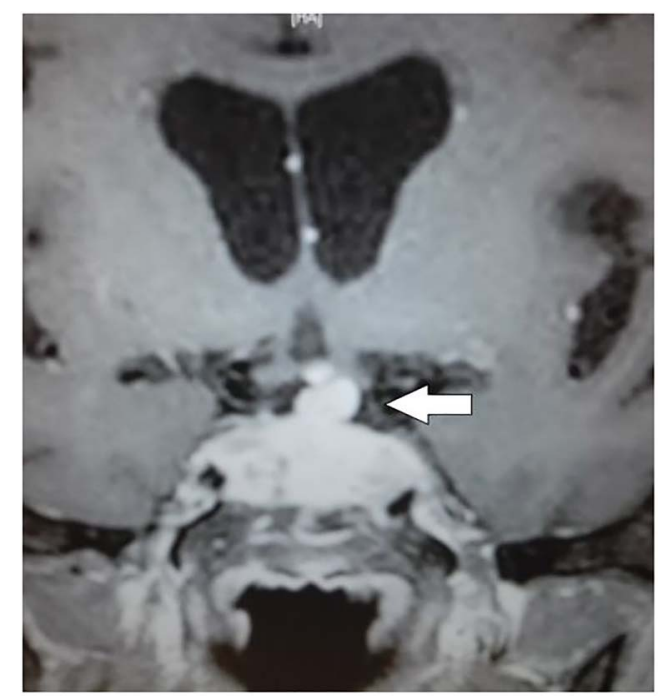

Figure 2 MRI T1W coronal image with gadolinium contrast shows heterogeneously contrast-enhanced pituitary mass with suprasellar extension abutting the optic chiasm and bilateral cavernous sinuses (arrow). T1W, T1-weighted.

pituitary and has an inhibitory effect on water excretion, contributing to fluid and electrolyte disturbances. ${ }^{3}$ Urgent corticosteroid replacement with hydrocortisone 100-200 mg intravenous bolus followed by continuous intravenous infusion of $2-4 \mathrm{mg} / \mathrm{h}$ is needed in patients with suspected hypoadrenalism. Prompt correction of electrolyte and fluid disturbances is life-saving. Neurosurgical decompression should be considered in patients with severe visual impairment. ${ }^{3}$ Long-term hormonal replacement therapy, including corticosteroids, desmopressin and sex hormones, is needed in about $80 \%$ of patients after pituitary apoplexy. Long-term follow-up with hormonal evaluation and eye assessment is required in this group of patients. ${ }^{3}$

\section{Learning points}

- Pituitary apoplexy presenting with bilateral oculomotor nerve palsy is rare.

- Acute secondary adrenal insufficiency, which is the major cause of mortality, is seen in about two-thirds of patients with pituitary apoplexy. Urgent replacement of corticosteroids, and correction of electrolyte and fluid disturbances are life-saving.

- Neurosurgical decompression should be considered in patients with severe visual impairment.

Contributors The authors have read and approved the manuscript for submission, and certify that each author made a substantial contribution so as to qualify for authorship.

Competing interests None declared.

Patient consent Obtained.

Provenance and peer review Not commissioned; externally peer reviewed.

\section{REFERENCES}

1 Komurcu HF, Ayberk G, Ozveren MF, et al. Pituitary adenoma apoplexy presenting with bilateral third nerve palsy and bilateral proptosis: a case report. Med Princ Pract 2012;21:285-7.

2 Perotti V, Dexter M. Post-partum pituitary apoplexy with bilateral third nerve palsy and bilateral carotid occlusion. J Clin Neurosci 2010;17:1328-30.

3 Ranabir S, Baruah MP. Pituitary apoplexy. Indian J Endocrinol Metab 2011;15(Suppl 3):S188-96.

Copyright 2015 BMJ Publishing Group. All rights reserved. For permission to reuse any of this content visit http://group.bmj.com/group/rights-licensing/permissions.

BMJ Case Report Fellows may re-use this article for personal use and teaching without any further permission.

Become a Fellow of BMJ Case Reports today and you can:

- Submit as many cases as you like

- Enjoy fast sympathetic peer review and rapid publication of accepted articles

- Access all the published articles

- Re-use any of the published material for personal use and teaching without further permission

For information on Institutional Fellowships contact consortiasales@bmjgroup.com

Visit casereports.bmj.com for more articles like this and to become a Fellow 